\title{
Matrix remodelling in dilated cardiomyopathy entails the occurrence of oncofetal fibronectin molecular variants
}

Ulrich Gabler, Alexander Berndt, Hartwig Kosmehl, Ulla Mandel, Luciano Zardi, Siegfried Müller, Axel Stelzner, Detlef Katenkamp

Institute of Pathology,

University of Jena,

Germany

U Gabler

A Berndt

H Kosmehl

D Katenkamp

Departments of Oral

Diagnostics, School of

Dentistry, University

of Copenhagen,

Denmark

U Mandel

Laboratory of Cell

Biology, Istituto

Nazionale per la

Ricerca sul Cancro,

Genoa, Italy

L Zardi

Clinic of Internal

Medicine, Department

of Cardiology,

University of Jena,

Germany

S Müller

Institute of Virology,

University of Jena,

Germany

A Stelzner

Correspondence to:

A Brandt, Institute of

Pathology, Friedrich-

Schiller-University,

Ziegelmuhlenweg 1 ,

D-07740 Jena, Germany

Accepted for publication

29 August 1995

\begin{abstract}
Objectives-To investigate whether disturbance of the cellular homoeostasis and integrity of cardiomyocytes in dilated cardiomyopathy (DCM) is accompanied by alterations in cell-matrix relations as indicated by changes in the deposition of fibronectin (FN) isoforms.
\end{abstract}

Design-Tissue from a case series of patients with DCM was investigated by immunohistochemistry with antibodies against FN (all variants, clone IST4), ED$A^{+}$FN (clone IST9), ED-B ${ }^{+}$FN (clone BC1), and oncofetal glycosylated FN (clone 5C10). The sites of de novo synthesis of FN were demonstrated by means of non-radioactive RNA in situ hybridisation (ISH) with biotinylated FN cDNA fragments as the probe.

Setting-University hospital.

Patients-Samples from 10 patients with clinical criteria and histological diagnosis of DCM and from 3 individuals with normal hearts.

Interventions-Samples were obtained by right ventricular endomyocardial biopsy.

Main outcome measure-Distribution of oncofetal FN variants in DCM hearts.

Results-Immunostaining of FN (IST4, all variants) showed a coarse interstitial network in normal and diseased myocardium. ED-A ${ }^{+}$FN was deposited as fine interstitial spots in normal myocardium and in DCM samples. Immunostaining for oncofetal glycosylated FN and ED-B ${ }^{+}$FN was not seen in normal adult myocardium, whereas myocardium from DCM patients showed focal and delicate staining in the interstitium. RNA ISH showed that these deposits resulted from local FN synthesis. Conclusion-The results accord with de novo expression of oncofetal FN variants in hearts from patients with DCM. The oncofetal FN variants may serve as disease markers in myocardium affected by DCM.

(Heart 1996;75:358-362)

Keywords: dilated cardiomyopathy; extracellular matrix; oncofetal fibronectins; in situ hybridisation

Dilated cardiomyopathy (DCM) is a heart muscle disease characterised by a decrease of the left ventricular ejection fraction and dilatation of both ventricles. ${ }^{1-3}$ The main histological changes are a disturbed tissue integrity and interstitial fibrosis, and both features affect outcome. $^{4}$

Cardiomyocytes need cell-cell contacts and defined cell-matrix relations to maintain normal physiological cell function. ${ }^{5-7}$ Therefore, all alterations to cardiomyocytes, including cellular degeneration, can change the composition of the extracellular matrix and vice versa. ${ }^{89}$ In normal myocardium, fibronectin (FN), laminin, and different collagens are present in the intercellular spaces between myocytes and in the vicinity of blood vessels ${ }^{10}$ and are significantly increased in diseased human myocardium. ${ }^{11}$ The increase in $\mathrm{FN}$ is particularly prominent, and eventually thick sheaths form around the myocardial cells. ${ }^{12}$ Though the role of $\mathrm{FN}$ in the organisation of connective tissue in vitro and in vivo has been studied, ${ }^{13} 14$ nothing is known about occurrence and molecular variants of $\mathrm{FN}$ in human myocardium. Molecular variants of $F N$ develop by alternative splicing or glycosylation. The molecular components, extra domains $\mathrm{A}$ and $\mathrm{B}\left(\mathrm{ED}-\mathrm{A}^{+}, \mathrm{ED}-\mathrm{B}^{+}\right)$, are skipped or included in a cell type specific manner. ED-A ${ }^{+}$and $E D-B^{+}$are included only in cellular FN. ${ }^{15}$ In adult tissues the distribution of ED-A $\mathrm{A}^{+}$and ED-B ${ }^{+} \mathrm{FN}$ expression is highly restricted. ${ }^{16}$ In addition the FN molecule may be subject to de novo glycosylation depending on the developmental stage of the tissue. ${ }^{17} 18$ These so-called oncofetal FN are known to occur in immature, tumorous, and reparative tissues. ${ }^{19-21}$ Are they also generated in hearts with DCM and if they are, how are they distributed?

Patients and methods

TISSUE MATERIAL

Endomyocard biopsy specimens from 10 patients with the clinical criteria and a histological diagnosis of DCM and three samples of normal human heart were examined. The diagnosis was confirmed by conventional histology. Fresh biopsy specimens, up to $3 \mathrm{~mm}$ in diameter, were snap frozen in fluid propane cooled by liquid nitrogen.

\section{IMMUNOHISTOCHEMISTRY}

Cryostat sections of the frozen tissue samples were fixed in ice cooled acetone for $15 \mathrm{~min}$ utes and examined immunohistochemically 

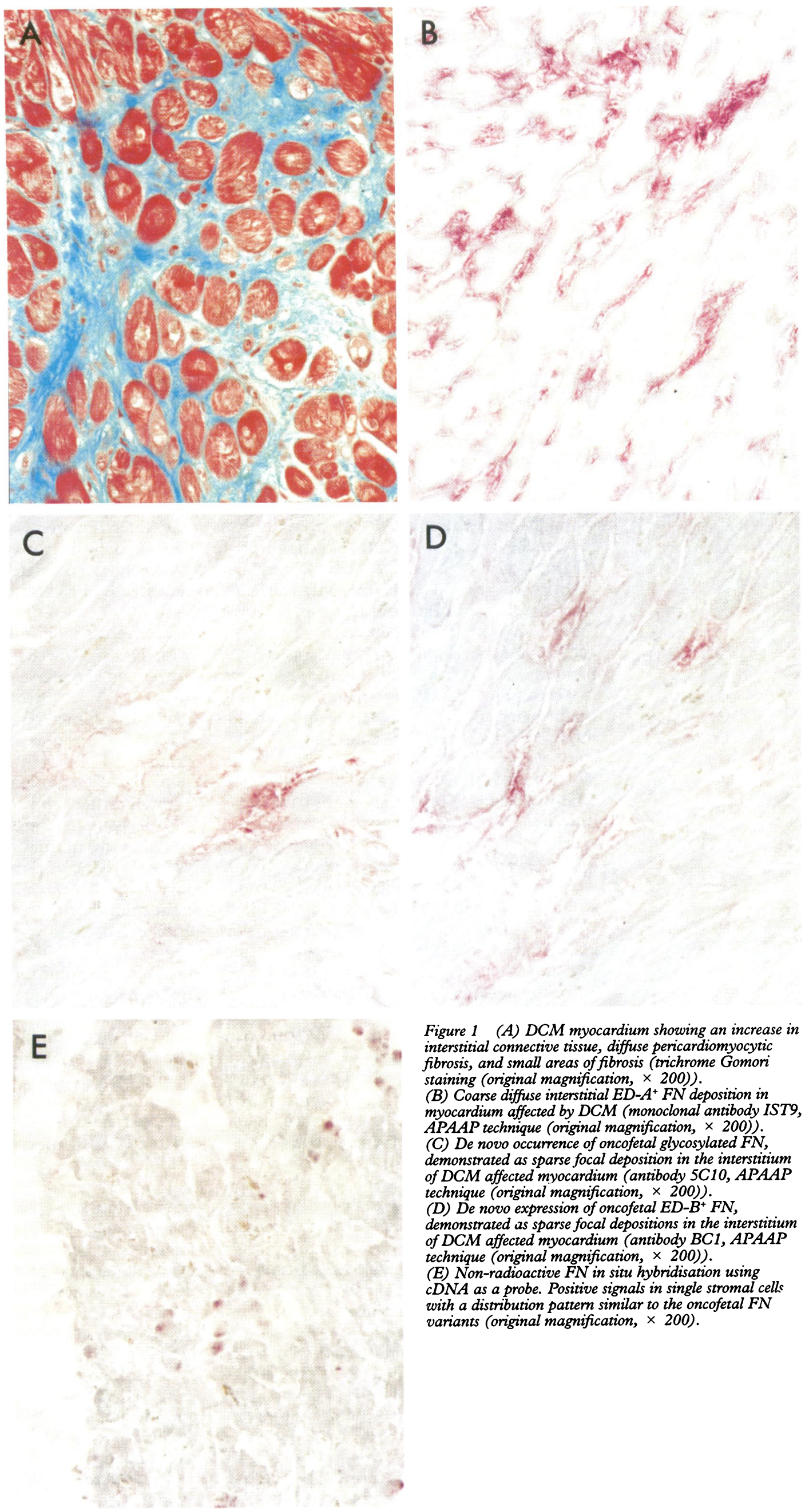

Figure 1 (A) DCM myocardium showing an increase in interstitial connective tissue, diffuse pericardiomyocytic fibrosis, and small areas of fibrosis (trichrome Gomori staining (original magnification, $\times 200$ )).

(B) Coarse diffuse interstitial $E D-A^{+} F N$ deposition in (B) Coarse diffuse interstitial ED- $A^{+}$FN deposition in
myocardium affected by DCM (monoclonal antibody IST9, APAAP technique (original magnification, $\times 200$ )). (C) De novo occurrence of oncofetal glycosylated $F N$, demonstrated as sparse focal deposition in the interstitium of DCM affected myocardium (antibody 5C10, APAAP technique (original magnification, $\times 200)$ ).

technique (original magnification, $\times$ De novo expression of oncofetal $E D-B^{+} F N$, demonstrated as sparse focal depositions in the interstitium of DCM affected myocardium (antibody BC1, APAAP technique (original magnification, $\times 200)$ ).

(E) Non-radioactive FN in situ hybridisation using cDNA as a probe. Positive signals in single stromal cells. with a distribution pattern similar to the oncofetal FN variants (original magnification, $\times 200$ ). 
with primary antibodies to all variants of $\mathrm{FN}$, including cellular and plasma FN (clone IST4, culture supernatant, diluted 1:20), ED-A $\mathrm{A}^{+} \mathrm{FN}$ (clone IST9, culture supernatant, diluted 1:500), ${ }^{22}{\mathrm{ED}-\mathrm{B}^{+}}^{\mathrm{FN}}$ (clone $\mathrm{BC} 1$, culture supernatant, diluted $1: 20),{ }^{23}$ oncofetal de novo glycosylated FN (clone 5C10, culture supernatant, diluted $1: 20){ }^{24}$ The antibody reaction was detected by the alkaline phosphatase antialkaline phosphatase (APAAP) method.

Sections were incubated for 30 minutes at room temperature with primary antibody. Then they were washed with Tris buffer and treated with rabbit anti-mouse immunoglobulin (IgG, Z-259, diluted 1:70, Dako, Glostrup, Denmark), and then with the mouse APAAPcomplex (Dako). Both incubations lasted for 30 minutes at room temperature. When primary polyclonal rabbit antibodies were used a second mouse anti-rabbit antibody (diluted 1:400, Dako) was used.

To increase the staining intensity, the incubation with the rabbit anti-mouse immunoglobulin and with the APAAP-complex was repeated twice. Naphtol-AS-biphosphate (Sigma, 2250, St Louis, USA) and new fuchsin (Merck, 4040, Darmstadt, Germany) were used as substrate and developer, respectively. To inhibit endogenous tissue enzyme activity the developing solution was supplemented with $0.25 \mathrm{mmol} / \mathrm{l}$ levamisole (Sigma, L-9756). For evaluation of immunostaining, the primary antibody was replaced by nonimmune serum as a negative control.

\section{MRNA IN SITU HYBRIDISATION}

Non-radioactive fibronectin in situ hybridisation was performed on cryostat sections of specimens snap frozen immediately after human heart biopsy. Tissue sections $(10 \mu \mathrm{m})$ were mounted on slides coated with $3 \%(v / v) 3-$ aminopropyltriethoxysilane in acetone, briefly air dried, and fixed in $4 \%(\mathrm{w} / \mathrm{v})$ paraformaldehyde in phosphate buffered saline for $20 \mathrm{~min}$ utes at $4^{\circ} \mathrm{C}$. Then slides were rinsed quickly in $70 \%$ ethanol and air dried. Sections were stored at $-70^{\circ} \mathrm{C}$ until they were processed. Before hybridisation the slide preparations were handled as follows: $20 \mathrm{~min}$ at room temperature in $0.2 \mathrm{MHCl}$, rinsed in $2 \times \mathrm{SSC}$, and $15 \mathrm{~min}$ at $37^{\circ} \mathrm{C}$ in $50 \mathrm{mM}$ Tris $\cdot \mathrm{HCl}, \mathrm{pH} 7 \cdot 6 /$ proteinase $\mathrm{K}$ $(1-5 \mu \mathrm{g} / \mathrm{ml})$. Slides were rinsed twice in distilled water, dehydrated in graded ethanol $(70 \%$ and $96 \%)$, and air dried.

PREPARATION OF LABELLED CDNA PROBE The cDNA for human $\mathrm{FN}^{25} 26$ was purchased from Gibco BRL, UK ( $1.4 \mathrm{~Kb}$, nucleic acids: 1993-3364) and digoxigenin labelled using the Nick Translation Kit and digoxigenin11-dUTP from Boehringer Mannheim, Germany.

Prehybridisation and hybridisation - The hybridisation solution contained $4 \times$ SSC, $50 \%$ $(\mathrm{v} / \mathrm{v})$ deionised formamide, $1 \times$ Denhardt's solution, $1 \mathrm{~m} M$ EDTA, 5\% (w/v) dextran sulphate, $100 \mu \mathrm{g} / \mathrm{ml}$ heat denatured calf thymus DNA, $100 \mu \mathrm{g} / \mathrm{ml}$ heat denatured transfer RNA, and $200 \mathrm{ng} / \mathrm{ml}$ digoxigenin labelled FN cDNA. Prehybridisation was carried out with hybridisa- tion medium without cDNA for $60 \mathrm{~min}$ at $37^{\circ} \mathrm{C}$ in a moist chamber. Then $50 \mu \mathrm{l}$ hybridisation solution containing $200 \mathrm{ng} / \mathrm{ml}$ probe were applied to each slide, RNAse free coverslips were mounted and hybridisation was allowed to proceed at $37^{\circ} \mathrm{C}$ overnight. Slides were then washed for $2 \mathrm{~h}$ in $10 \mathrm{mM}$ Tris $\cdot \mathrm{HCl}, \mathrm{pH} 7 \cdot 6 / 2$ $\times \mathrm{SSC} / 50 \%$ formamide $/ 1 \mathrm{mM}$ EDTA followed by $1 \mathrm{~h}$ at $55^{\circ} \mathrm{C}$ in OmniBuff (JenaBioTech and WAK Chemie Medical, Bad Homburg, Germany) and rinsed in Omnibuff at room temperature. Hybridised cDNA was detected using an anti-digoxigenin antibody (Boehringer Mannheim, Germany) and the APAAP technique mentioned above.

No probe hybridisation and RNAse predigestion were used as negative control and specificity controls, respectively.

\section{Results}

In normal adult human hearts immunostaining of FN (IST4, all variants) showed a delicate interstitial network. ED-A ${ }^{+} \mathrm{FN}$ (antibody IST9) deposited as fine interstitial spots. Oncofetal glycosylated FN (antibody 5C10) and $\mathrm{ED}-\mathrm{B}^{+} \mathrm{FN}$ (antibody $\mathrm{BC} 1$ ) could not be seen.

Conventional histology of biopsies of hearts with DCM showed hypertrophied cardiomyocytes and varying degrees of interstitial fibrosis (fig 1A). A few lymphocytes and histiocytes could sometimes be seen in the interstitium. The demonstration of the total FN using the antibody IST4 showed increased immunostaining of a coarse interstitial network. Immunohistochemistry showed slight $\mathrm{ED}-\mathrm{A}^{+}$ FN deposits in hearts with DCM resembling those in the normal adult hearts (fig 1B). In contrast to the normal adult myocardium there was a focal interstitial immunoreaction indicating de novo glycosylated FN (fig 1C) and $\mathrm{ED}^{-\mathrm{B}^{+}} \mathrm{FN}$ (fig 1D) in failing DCM hearts. These FNs were irregularly distributed in the interstitium and were visible as small ribbons. Non-radioactive in situ hybridisation showed FN mRNA in the fibrotic interstitial areas of myocardium in DCM patients with stronger focal staining in single cells (fig 1E). In situ hybridisation also showed an even distribution pattern of immunohistochemically demonstrated ED-B ${ }^{+}$FN and de novo glycosylated $\mathrm{FN}$ as well as $\mathrm{FN}$ synthesis.

\section{Discussion}

Maintenance of the structural and functional integrity of heart muscle requires a defined extracellular matrix composition. ${ }^{27-29}$ Numerous studies have described changes in extracellular matrix composition in the course of developmental and disease processes of the heart. ${ }^{30-32} \mathrm{FN}$, one of the major non-collagenous proteins of the extracellular matrix, is increased in diseased human myocardium ${ }^{11}$ and the increase in FN (all molecular variants) in DCM myocardium that we found accords with this earlier study.

The different $\mathrm{FN}$ isoforms are derived from a single gene by alternative processing of the 


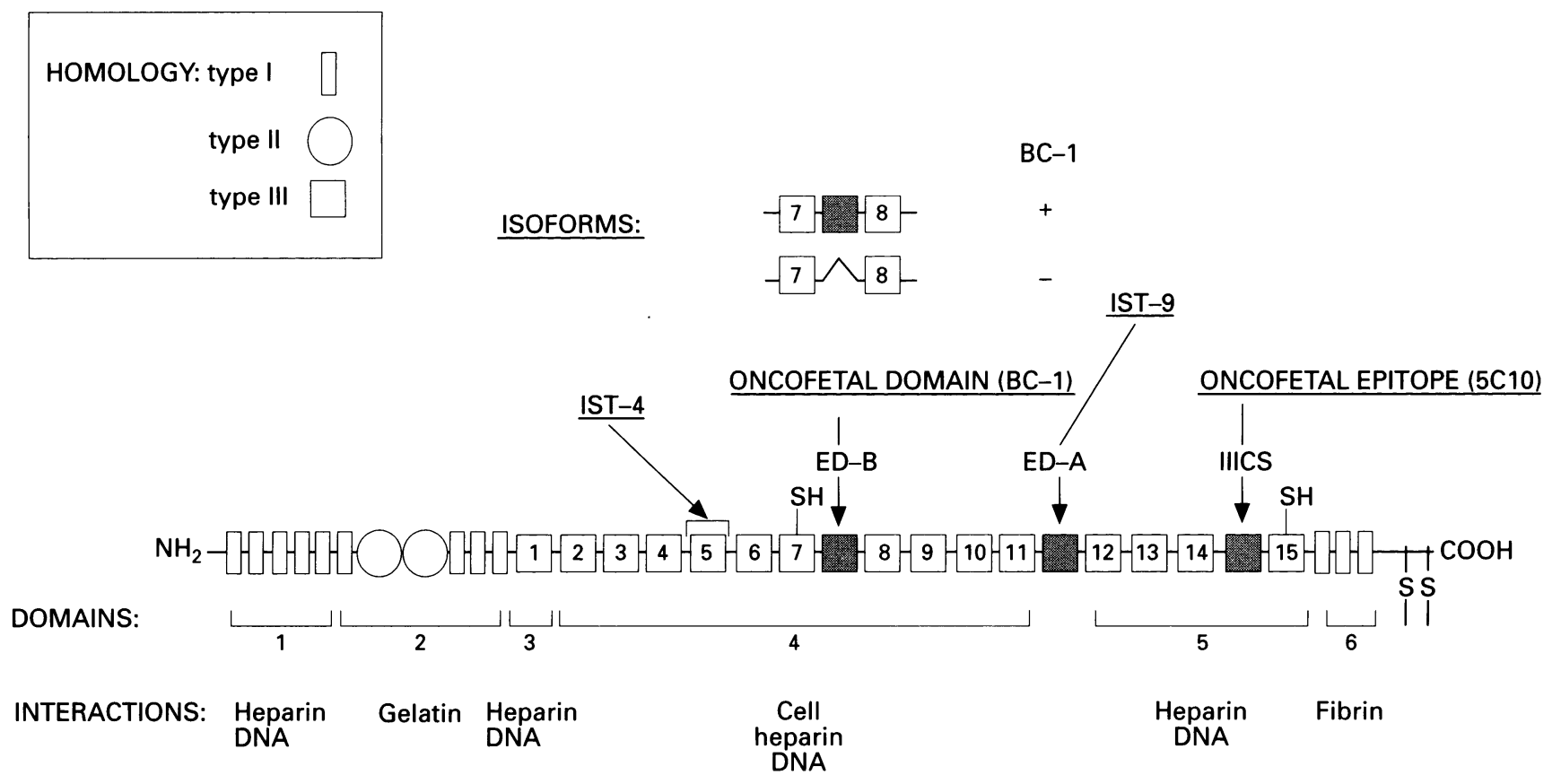

Fibrin

Figure 2 Model of the domain structure of a subunit of human FN. The oncofetal domain ED-B and the oncofetal epitope recognised by the monoclonal antibody $5 \mathrm{C} 10$ are indicated. The figure also indicates the internal homologies, the three sites of alternative splicing $\left(E D-B^{+}, E D-A^{+}\right.$, and IIICS), the major macromolecules interacting with the various FN domains, and the two isoforms generated by alternative splicing of the ED-B sequence with the reactivity of these isoforms with the monoclonal antibody $B C 1$.

primary RNA transcript (alternative splicing) or by post-translational modifications in the Cterminal region of the molecule with an O-linked glycosylation. ${ }^{183} \mathrm{FN}$ has three sites of alternative splicing, the ED-A domain, the ED-B domain, and the IIICS region. ${ }^{34}$ The inclusion of the alternative type III repeats, ED-A and the ED-B, in the FN molecule as well as de novo glycosylation can be detected by specific monoclonal antibodies: IST $9,^{22} \mathrm{BC} 1,{ }^{23}$ and $5 \mathrm{Cl}^{23},{ }^{24}$ respectively. Figure 2 shows a model of the domain structure of a subunit of human FN and the epitopes recognised by the applied antibodies. Little or no variant $\mathrm{FN}$ is present in normal adult tissue. ${ }^{15}$ In this study very little $\mathrm{ED}-\mathrm{A}^{+}$ $\mathrm{FN}$ and no ED-B ${ }^{+} \mathrm{FN}$ and de novo glycosylated $\mathrm{FN}$ was detected in normal heart muscle. $\mathrm{ED}-\mathrm{A}^{+}$and $\mathrm{ED}-\mathrm{B}^{+} \mathrm{FN}$ mRNA is increased in embryonic and malignant tissues. ${ }^{35} 36$ Furthermore, the de novo glycosylation of $\mathrm{FN}$ is associated with cellular immaturity, cancer formation, and the malignancy of breast, gastric, and oral carcinomas. ${ }^{17}$ Such FN variants are termed "oncofetal". 37 Recently, Fahradian and coworkers pointed to the importance of differential splicing of FN during cardiac ontogeny and development of hypertrophy in the rat. ${ }^{40}$ As far as we know, ours is the first description of de novo expression of ED-B ${ }^{+}$ and de novo glycosylated $\mathrm{FN}$ isoforms in human hearts with DCM. These FN isoforms indicate an altered extracellular matrix and may be important to the progress of myocardial damage. Nevertheless, our results do not establish that oncofetal fibronectin deposition is specific to DCM. It is possible that de novo synthesis of fibronectin isoforms is associated with the attendant fibrosis itself rather than with dilatation. Experimental studies on fetal and neonatal rat cardiomyocytes showed a high affinity to $\mathrm{FN}$ in contrast to adult myocytes. ${ }^{41}$ This corresponds with a transient physiological up regulation of collagen synthesis in utero and immediately post partum. ${ }^{42}$ Collagen synthesis is also increased in DCM (interstitial myocardial fibrosis).

The irregular multifocal distribution of oncofetal fibronectin variants on the one hand shows that the whole heart is involved in the disease process of DCM and on the other hand shows multiple active disease foci in the myocardium.

Though the functional role of the oncofetal FNs is not well understood ${ }^{15}$ our results suggest that they may modulate cellular adhesion mechanisms in cardiomyopathy. The occurrence of oncofetal molecular $\mathrm{FN}$ variants is likely to be associated with a decreased cellular adhesion. ${ }^{43}$ The simultaneous de novo expression of tenascin in DCM, which is known as adhesion modulating factor ${ }^{45}$ accords with the concept that a change of cell adhesion in DCM is a significant aspect of the diagnosis. ${ }^{46}$

The results of FN mRNA in situ hybridisation showed that oncofetal isoforms of $\mathrm{FN}$ in DCM are generated by stromal cells with a fibroelastic appearance. A more precise characterisation of the cell type responsible for synthesis of oncofetal fibronectins will be the aim of further investigations. We do not know the mechanisms that induce the synthesis of oncofetal FNs in DCM. Growth factors (released from damaged cardiomyocytes), which are known to modulate $\mathrm{FN}$ splicing, may be involved. ${ }^{97}$

1 Abelmann WH, Lorell $\mathrm{BH}$. The challenge of cardiomyopathy f Am Coll Cardiol 1989;131:1219-39. 2 Kasper EK, Agema WRP, Hutchins GM, Deckers JW, 
Hare JM, Baughman $\mathrm{KL}$. The causes of dilated cardiomyopathy: a clinicopathologic review of 673 consecudiomyopathy: a clinicopathologic review of 673

3 Roberts WC, Siegel RJ, McManus BM. Idiopathic dilated cardiomyopathy: analysis of 152 necropsy patients. $A m \mathcal{F}$ Cardiol 1987;60:1340-55.

4 Arbustini E, Gavazzi A, Pozzi R. The morphologic spectrum of dilated cardiomyopathy and its relation to immune-response genes. Am f Cardiol 1989;64:991-5.

5 Langbein L, Kosmehl H, Katenkamp D, Neupert G, Stille K-J. Experimental induced murine rhabdomyosarcoma-correlation between cellular contacts, matrix formation and

6 Vogel W, Kosmehl H, Katenkamp D, Langbein L Differentiation dependent matrix formation (fibronectin and laminin) in an experimental murine rhabdomyosarcoma model. Acta Histochem 1990;90:181-8.

7 von der Mark K, Öcalan M. Antagonistic effects of laminin and fibronectin on the expression of the myogenic phenotype. Differentiation 1989;40:150-7.

8 Samuel JL, Barrieux A, Dufour S, Dubus I, Contard F, Kotelyansky V, et al. Accumulation of fetal fibronectin mRNAs during development of rat cardiac hypertrophy induced by pressure overload. I Clin Invest 1991;88. 1737-46.

9 Villareal FJ, Dillmann WH. Cardiac hypertrophy-induced changes in mRNA levels for TGF- $\beta_{1}$, fibronectin, and collagen. Am F Physiol 1992;262:1861-6.

10 Speiser B, Weihrauch D, Riess CF, Schaper J. The extracellular matrix in human cardiac tissue part II: vimentin, laminin, and fibronectin. Cardioscience 1992;3:41-9.

11 Schaper J, Speiser B. The extracellular matrix in failing human heart. Basic Res Cardiol 1992;87:303-9.

12 Kawahara E, Mukai A, Oda Y, Nakanishi I, Iwa T. Left ventriculotomy of the heart: tissue repair and localization of collagen types I, II, III, IV, V, VI and fibronectin. Virch Arch A 1990;417:229-36.

13 Adams JC, Watt FM. Regulation of development and differentiation by the extracellular matrix. Developmen 1993;117:1183-98.

14 Shekonin B, Domagatsky S, Idelson G, Koteliansky V. Participance of fibronectin and various collagen types in the formation of fibrous extracellular matrix. $\mathcal{F} \mathrm{Mol} \mathrm{Cell}$ Cardiol 1988;20:501-8.

15 Schwarzbauer JE. Alternative splicing of fibronectin: three variants, three functions. BioEssays 1991;13:527-33.

16 Vartio T, Laitinen L, Narvanen O, Cutolo M, Thornel I Zardi L, et al. Differential expression of the ED sequence-containing form of cellular fibronectin in embryonic and adult human tissues. F Cell Sci 1987 88:419-30.

17 Mandel U, Gaggero B, Reibel J, Therkildsen $\mathrm{MH}_{\text {, }}$ Dabelsteen E, Clausen H. Oncofetal fibronectins in ora carcinomas: correlation of two different types. APMIS 1994;102:695-702.

18 Matsuura $H$, Hakomori $S$. The oncofetal domain of fibronectin defined by monoclonal antibody FDC-6: its presence in fibronectins from fetal and tumor tissues and its absence in those from normal adult tissues and plasma. Proc Natl Acad Sci USA 1985;82:6517-21.

19 Carsons S, Clausen H, Wolf J. Expression of a develop Carsons $\mathrm{S}$, Clausen $\mathrm{H}$, Wolf $\mathrm{J}$. Expression of a develop-
mentally regulated epitope on fibronectins from the synmentally regulated epitope on fibronectins from the syn-
ovial fluid of patients with rheumatic disease. $\mathcal{F}$ Reumatol ovial fluid of patients

20 Ffrench-Constant $\dot{C}$, Hynes RO. Alternative splicing of fibronectin is temporally and spatially regulated in the chicken embryo. Developement 1989;106:375-88.

21 Zardi L, Carnemolla B, Siri A, Petersen TE, Paolella G Sebastio $\mathrm{G}$, et al. Transformed human cells produce a new fibronectin isoform by preferential alternative splicing of a previously unobserved exon. EMBO $\mathcal{f} 1987$;6: $2337-42$

22 Borsi L, Carnemolla B, Castellani P, Rossellini C, Vecchio $D$, Allemanni G, et al. Monoclonal antibodies in the analysis of fibronectin isoforms generated by alternative splicing of mRNA precursors in normal and transformed human cells. $\mathcal{F}$ Cell Biol 1987;104:595-600.

23 Carnemolla B, Leprini A, Allemanni G, Saginati M, Zardi L The inclusion of the type III repeat $E D-B$ in the fibronectin molecule generate conformational modifications that unmask a cryptic sequence. $\mathcal{F}$ Biol Chem 1992 267:24689-92.

24 Mandel U, Therkildsen MH, Reibl J, Sweeney B, Matsuura H, Hakomori S-I, et al. Cancer-associated changes in glycosylation of fibronectin. APMIS 1992, 100:817-26.
25 Kornblihtt AR, Vibe-Pedersen K, Baralle FE. Isolation and characterization of cDNA clones for human and bovine

26 Kornblihtt AR, Umezawa K, Vibe-Pedersen K, Baralle FE ing may generate at least 10 polypeptides from a single gene. $E M B O \mathcal{F} 1985 ; 4: 1755-90$

27 Ahumada G, Rennard S, Figueroa A, Silver M. Cardiac fibronectin: Developmental distribution and quantitative comparison of possible sites of synthesis. $\mathcal{F} \mathrm{Mol} \mathrm{Cell}$ Cardiol 1981;13:667-78.

28 Carver W, Burgess ML, Jyring R, Terracio L, Borg TK. Extracellular matrix expression, organisation and interaction with heart myocytes during development and disease. In: Figulla HR, Kandolf R, McManus B, eds Idiopathic Dilated Cardiomyopathy. Berlin: Springer, 1993:

29 Caulfield JB, Borg TK. The collagen network in the heart. Lab Invest 1979;40:354-71.

30 Borg TK, Terracio L. Interaction of the extracellular matrix with cardiac myocytes during development and disease. In: Robinson T, ed Issues in biomedicine. Basel: Karger, 1990:113-29.

31 Weber KT, Pick R, Silver MA, Moe GW, Janicki JS, Zucker HI, et al. Fibrillar collagen and remodelling of dilated canine left ventricle. Circulation 1990;82: 1387-401.

32 Tazelaar HD, Gay RE, Rowan RA, Billingham ME, Gay S. Collagen profile in the transplanted heart. Hum Pathol 1990;21:424-8.

33 Matsuura $\mathrm{H}$, Takio $\mathrm{K}$, Titani $\mathrm{K}$, Greene $\mathrm{T}$, Levery SB, Salyan MEK, et al. The oncofetal structure of human
fibronectin defined by monoclonal antibody FDC-6. 7 Biol Chem 1988;263:3314-22.

34 Schwarzbauer JE. The fibronectin gene. In: Sandell LJ, Boyd CD, eds Extracellular matrix genes. San Diego: Academic Press, 1990:195-219.

35 Oyama F, Hirohashi S, Shimosato Y, Titani K, Sekiguchi $\mathrm{K}$. Oncodevelopmental regulation of the alternative splicing of fibronectin pre-messenger RNA in human lung tissues. Cancer Res 1990;50:1075-8.

36 Oyama F, Hirohashi S, Sakamoto M, Titani K, Sekiguchi $\mathrm{K}$. Coordinate oncodevelopmental modulation of alternative splicing of fibronectin pre-messenger RNA at ED$\mathrm{A}, \mathrm{ED}-\mathrm{B}$, and CS1 regions in human liver tumors. Cancer Res 1993;53:2005-11.

37 Carnemolla B, Balza E, Siri A, Zardi L, Nicotra MR, Bigotti A, et al. A tumor-associated fibronectin isoform generated by alternative splicing of messenger RNA precursors. $\mathcal{F}$ Cell Biol 1989;108:1139-48.

38 David L, Mandel U, Clausen H, Sobrinho-Simões $M$. Immunohistochemical expression of oncofetal fibronectin in benign and malignant lesions of the stomach. Eur f Cancer 1993;29A:2070-1.

39 Ffrench-Constant C, Van De Water L, Dvorak HF, Hynes RO. Reappearance of an embryonic pattern of fibronectin splicing during wound healing in the adult rat. $\mathcal{F}$ Cell Biol 1989;109:903-14.

40 Fahradian F, Barrieux A, Lortet S, Marotte F, Oliviero P, Rappaport L, et al. Differential splicing of fibronectin pre-messenger ribonucleic acid during cardiac ontogeny and development of hypertrophy in the rat. Lab Invest 1994;71:552-9.

41 Borg TK, Terracio L. Cellular adhesion to artificial substrates and long term culture of adult cardiac myocytes. In: Clark WA, Decker RS, Borg TK, eds. Biology of isolated adult cardiac myocytes. New York: Elsevier, 1988 14-24.

42 Borg TK. Development of the connective tissue network in the neonatal hamster heart. Anat Rec 1982;165:435-44.

43 Olden K. Adhesion molecules and inhibitors of glycosylation in cancer. Sem Cancer Biol 1993;4:269-76.

44 Chiquet-Ehrismann R. Tenascin and other adhesion-modulating proteins in cancer. Sem Cancer Biol 1993;4:301-10.

5 Riou JF, Umbhauer M, Shi DL, Boucaut JC. Tenascin: a potential modulator of cell-extracellular matrix interactions during vertebrate embryogenesis. Biol Cell 1992;75: $1-9$.

46 Gabler U, Kosmehl H, Masri-Zada A, Berndt A, Leder U, Müller S, et al. Tenascin in Myokardbiopsien als immunohistochemischer Marker einer gestörten myopathie (DCM) [abstr]. Z Kardiol 1994;38(suppl 1): 216.

47 Parker TG, Schneider MD. Growth factors, proto-oncogenes, and plasticity of the cardiac phenotype. Annu Rev Physiol 1989;53:179-200. 